\title{
Performance analysis of glazed PVT collectors for multifamily building
}

\author{
Nikola Pokorny ${ }^{1}$, Tomas Matuska ${ }^{1}$ \\ ${ }^{1}$ UCEEB, CTU in Prague, Bustehrad 273 43, Trinecka 1024, Czech Republic
}

\begin{abstract}
The paper deals with performance analysis of potential application of glazed photovoltaicthermal collector for domestic hot water preparation for multifamily building in European climatic conditions. Two different solutions are studied, glazed photovoltaic-thermal collectors integrated in the building envelope and glazed photovoltaic-thermal collectors fixed on the roof of the building. Moreover, the paper presents a comparison with conventional side by side installation of solar thermal collectors and photovoltaic panels to show the benefit of photovoltaic-thermal collectors. Simulation analysis has been done in TRNSYS with use of developed and validated mathematical model of glazed photovoltaic-thermal collector.
\end{abstract}

\section{Introduction}

Glazed photovoltaic-thermal (PVT) collector represents a technology combining the solar thermal collector and photovoltaic module in a single component. Simultaneous production of power and heat from limited area of building envelope (roof, façade) can increase the fraction of renewable energy sources on energy supply for buildings. In contrast to unglazed PVT collectors widely available on the market today, glazed PVT collectors allow sufficient temperature levels for domestic hot water preparation similar to conventional solar thermal systems, while electricity production is reduced due to additional glazing and higher operation temperatures [1]. The principle barrier for the glazed PVT collector application is the low resistance of common ethylene-vinyl acetate (EVA) encapsulation of PV cells to excessive thermal exposure. Maximum operation temperature of EVA laminate ranges around $85^{\circ} \mathrm{C}$ [2] while the stagnation temperature for glazed solar collectors could reach $120{ }^{\circ} \mathrm{C}$ to $180{ }^{\circ} \mathrm{C}$. At such temperature levels, EVA encapsulation decomposes to acetic acid, which causes the corrosion of PV cell contacts, delamination and degradation of layer transparency. There are several attempts to avoid this problem by increasing heat losses during stagnation period $[3,4]$. The concept of glazed PVT collector presented in the paper focuses on the temperature resistant encapsulant for PV cells based on polysiloxane gel [5]. Polysiloxane gel offers a large range of operation temperatures (from -60 to $+250{ }^{\circ} \mathrm{C}$ ), high transparency for solar radiation and allows the compensation of thermal dilatation stresses thanks to low modulus of elasticity [6].

A specific option for the glazed PVT collector application comes with the integration into façade envelope as a prefabricated unit. PVT collector replaces a part of the façade construction and the concept of envelope considered as an energy loss in past turns to energy active envelope. On the other hand, façade integration of PVT collectors becomes also an architectural issue (surface color, texture of component, etc.). Façades are also sensitive to shading by other buildings or trees.

\section{Glazed PVT collectors}

Glazed PVT collector both in separate and façade integration alternative is based on sandwich unit with monocrystalline PV cells encapsulated in the polysiloxane gel layer between double glazing and copper sheet with pipe register, see in Fig. 1.

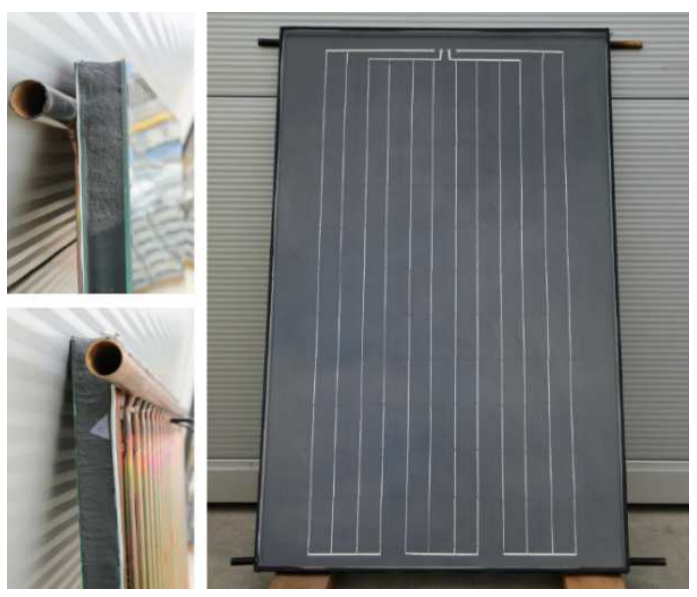

Fig. 1. Fabricated PVT sandwich unit

Prototypes of PVT collectors in both alternatives for

*Corresponding author: nikola.pokorny@cvut.cz 
testing have been fabricated. Double glazing with a gap between glass panes $24 \mathrm{~mm}$ filled with argon has been used. Absorber has been made from copper sheet $(0.2 \mathrm{~mm})$ soldered to pipe register made from risers of $8 \mathrm{~mm}$ in diameter. Distance between the copper risers was $50 \mathrm{~mm}$. The sandwich unit can be integrated into standard collector frame made of aluminum profiles or integrated into component of curtain walling façade.

Separate collector unit size is $1.04 \mathrm{~m} \times 1.64 \mathrm{~m}$ with gross area $1.71 \mathrm{~m}^{2}$. To decrease the heat losses low emissivity coating has been applied at the inner glass of double glazing surface. In total $6 \times 11$ monocrystalline PV cells at size $125 \times 125 \mathrm{~mm}$ have been used. The PV cell reference efficiency declared by manufacturer is $18.8 \%$ under STC (standard test conditions, i.e. reference temperature $25{ }^{\circ} \mathrm{C}$ and solar irradiance $1000 \mathrm{~W} / \mathrm{m}^{2}$ ). Gross area of the collector has been filled with PV cells for $60 \%$ (packing factor related to gross area). Absorber has been insulated by $30 \mathrm{~mm}$ of mineral wool on the back, edge side was insulated by $10 \mathrm{~mm}$ of mineral wool.

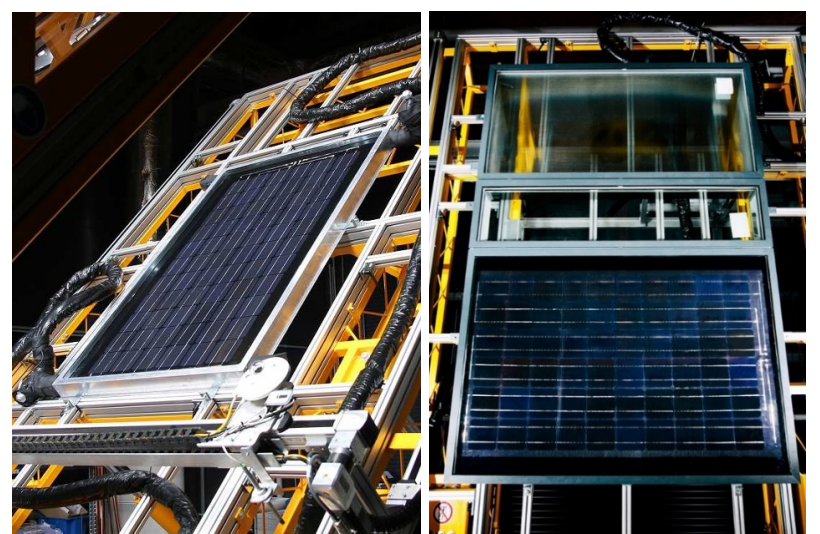

Fig. 2. Separate PVT collector in standard frame (left) and facade integrated PVT collector (right) at test stand

Size of collector unit integrated into façade module is $1.04 \mathrm{~m} \mathrm{x} 1.46 \mathrm{~m}$ with gross area $1.52 \mathrm{~m}^{2}$. Monocrystalline cells used were identical with separate alternative, but only 60 cells have been used. Similar packing factor has been achieved. Integration of PVT sandwich unit into curtain walling façade element results in total insulation thickness behind the absorber $160 \mathrm{~mm}$. No low emissivity coating has been applied for glazing in this prototype.

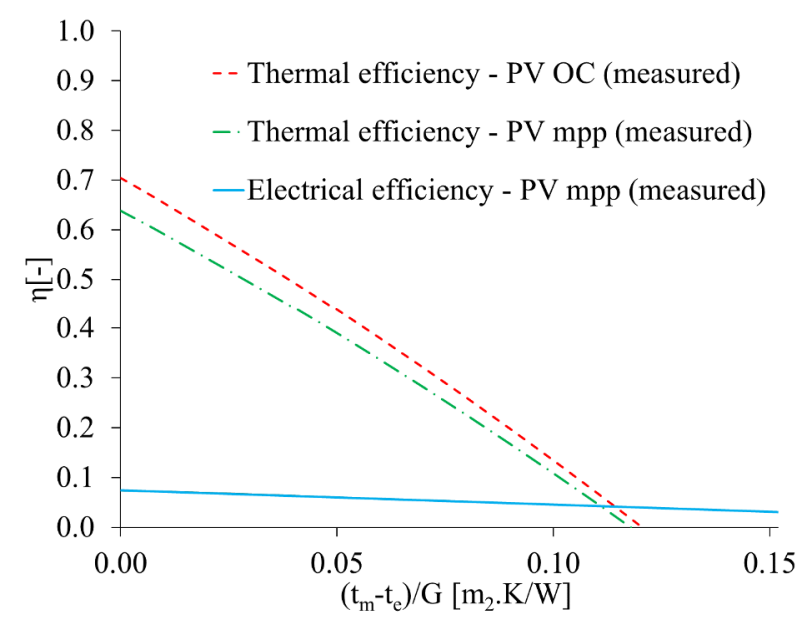

Fig. 3. Measured thermal and electrical characteristics for separate PVT collector (related to gross area)

Prototypes have been tested at Solar laboratory (UCEEB CTU) with use of indoor solar simulator. The thermal performance has been determined according to EN ISO 9806. Characteristic of thermal efficiency has been tested in two modes. In the hybrid mode, the PV part was connected to maximum power point (MPP) tracker with measured load. In open circuit mode, the PVT collector thermal performance was tested without electric load. Thermal and electric characteristics have been related to gross area. Fig. 3 shows the tested characteristics of thermal and electrical efficiency for separate PVT collector module with low-e coating. Fig. 4 shows the efficiency characteristics for façade integrated PVT collector without low-e coating.

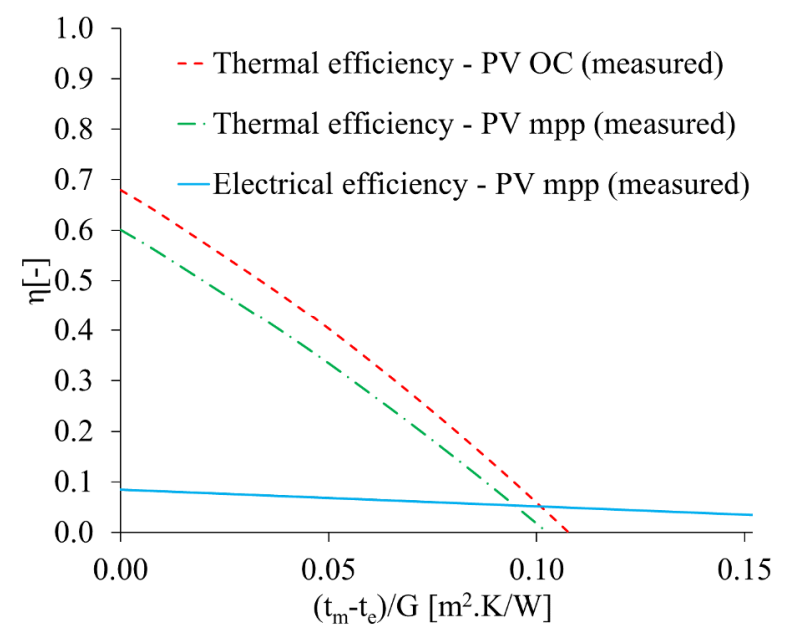

Fig. 4. Measured thermal and electrical characteristics for integrated PVT collector (related to gross area)

\section{Analysis for multifamily building}

Glazed PVT collectors are convenient for applications with uniform heat and electricity load during the year and also for building with limited space on the roof for installation of solar collectors. Therefore, solar domestic 
hot water preparation for multifamily building is target application.

\subsection{Modelling of PVT collector}

Nowadays, several steady state models etc. [7, 8] and dynamic models of PVT collector etc. [9, 10, 11] are known in scientific literature. In TRNSYS simulation software there is type 50b [12] which does not consider a detailed construction of the collector and change of important collector parameters during the different climate and operational conditions (collector heat loss coefficient, fin efficiency factor, etc.). Due to this fact, mathematical model has been developed with use of Florschuetz approach [13]. The model uses detailed energy flows balance of PVT collector, expanded for photovoltaic conversion. Calculation procedure of the model solves the external and internal energy balance of the PVT absorber. Both balances proceed in the iteration loop, more in [14]. The presented mathematical model does not consider diffuse incidence angle modifier. Undisputed advantage of implemented model is the possibility to define a number of design and physical parameters of collector configuration: geometry, electrical and thermo-physical properties of PV cells, thermo-physical properties of materials used in PVT collector, etc. Thanks to validation of the mathematical model based on the testing, low emissivity coating has been considered for both investigated alternatives: separate PVT collector on the roof and PVT collector integrated into façade. Inputs of the model are conventional: weather and operation conditions. Main outputs of the model are usable thermal and electric power, absorber temperature and outlet liquid temperature.

\subsection{SDHW system in multifamily building}

The studied multifamily building has 45 flats occupied with 100 occupants. Gross floor size of the building is $25 \mathrm{~m} \times 19 \mathrm{~m}$ with height $25.2 \mathrm{~m}$ (9 floors). The total floor area of the building is $475 \mathrm{~m}^{2}$, south façade area is $630 \mathrm{~m}^{2}$. Solar heat is used for DHW preparation, solar electricity is used for the building appliances load. Heat demand for hot water use in the building is $116 \mathrm{MWh} / \mathrm{a}$. Electricity demand for the building is $96 \mathrm{MWh} / \mathrm{a}$.

Analyses have been performed for three different climate zones in Europe with different annual solar irradiation: Madrid (1864 kWh/m².a), Prague $\left(1115 \mathrm{kWh} / \mathrm{m}^{2} . \mathrm{a}\right)$ and Helsinki (1153 kWh/m².a). Three different solar systems with glazed solar PVT liquid collectors were compared with conventional side by side installation of solar thermal collectors and PV panels. In every studied case $100 \%$ of PVT area was compared with side by side installation of same area (50\% of solar thermal collectors and $50 \%$ of PV panels). Side by side installation combined the state-of-art solar thermal collectors and photovoltaic modules with identical monocrystalline PV cells as used in hybrid PVT collectors. Solar heat and power systems have been modelled in TRNSYS environment with use of the developed model for glazed PVT collector [14].

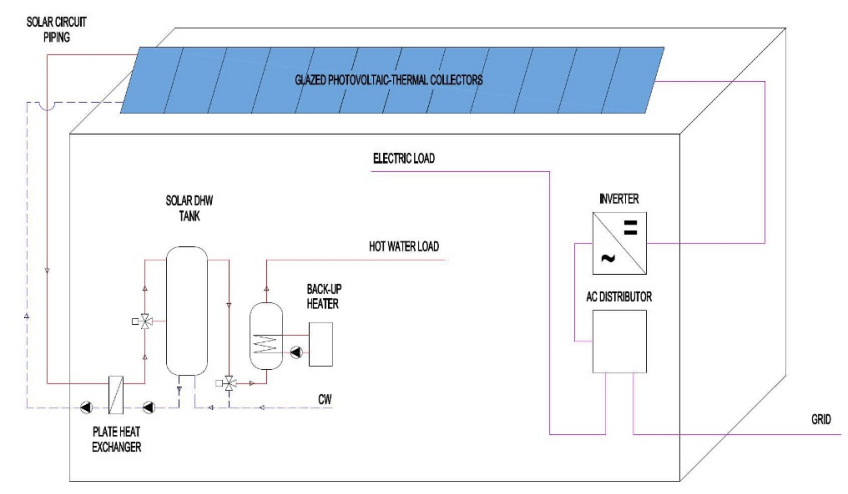

Fig. 5. Simplified scheme of the solar energy system

Simplified scheme of the solar energy system is shown in Fig. 5. Solar thermal part of the investigated system variants consists of several main components specified in Tab. 1. Solar collectors were considered with slope $45^{\circ}$ for roof installation and $90^{\circ}$ for integration into façade. For side-by-side alternative an inclination $30^{\circ}$ has been used for PV panels. Moreover, there were considered following parameters: orientation to south, insulated pipes of collector loop, heat exchanger and insulated solar DHW storage tank. Parameters of main components for the solar thermal systems alternatives are dependent on collector field area considered in the different variants. Dimension of the collector loop pipes is based on specific mass flow rate $15 \mathrm{~kg} / \mathrm{h} . \mathrm{m}^{2}$ of collector area (low flow solar system). Pipes length of solar collector loop in outdoor environment is $80 \mathrm{~m}$, length of pipes inside the building is $80 \mathrm{~m}$. For façade integrated alternative collector loop pipes were considered fully installed in indoor environment. Solar tank volume has been determined from specific value $501 / \mathrm{m}^{2}$ of collector area (see Tab. 1). Efficiency of solar plate heat exchanger is $80 \%$. PV power system is a conventional grid-on system with DC/AC inverter. Total system losses are considered $10 \%$. Whole PV electricity production has been assumed to be consumed for the building appliances load.

Table 1. Solar energy system parameters

\begin{tabular}{|c|c|c|c|c|}
\hline Variant & $\begin{array}{c}\text { Solar } \\
\text { thermal } \\
\text { area } \\
{\left[\mathbf{m}^{2}\right]}\end{array}$ & $\begin{array}{c}\text { Solar } \\
\text { tank } \\
\text { volum } \\
\mathbf{e}\left[\mathbf{m}^{\mathbf{3}}\right]\end{array}$ & $\begin{array}{c}\text { Collector } \\
\text { loop } \\
\text { dimensio } \\
\mathbf{n}[\mathbf{m m}]\end{array}$ & $\begin{array}{c}\text { Collector } \\
\text { loop } \\
\text { insulation } \\
{[\mathbf{m m}]}\end{array}$ \\
\hline R - PVT & 165 & 8.3 & $35 \times 1.5$ & 25 \\
\hline R-50PV50PT & 82.5 & 4.1 & $28 \times 1.5$ & 25 \\
\hline F9 - PVT & 140 & 7 & $35 \times 1.5$ & 25 \\
\hline F9-50PV50PT & 70 & 3.5 & $28 \times 1.5$ & 25 \\
\hline F5 - PVT & 78 & 3.9 & $28 \times 1.5$ & 25 \\
\hline F5-50PV50PT & 39 & 1.9 & $22 \times 1.5$ & 19 \\
\hline
\end{tabular}

\subsection{Roof installation of the solar energy system}

Available solar collector field area on the building roof is $165 \mathrm{~m}^{2}$ (35\% of total roof area). 48 collectors with gross area $3.43 \mathrm{~m}^{2}$ are considered (see in Fig. 6.). Side 
by side installation consists of PV panels $\left(82.5 \mathrm{~m}^{2}\right)$ and solar thermal collectors $\left(82.5 \mathrm{~m}^{2}\right)$ It means, that side by side installation has a same installation area as a PVT alternative. Alternative with PVT collectors uses the whole available roof area $165 \mathrm{~m}^{2}$, see Fig. 6 .

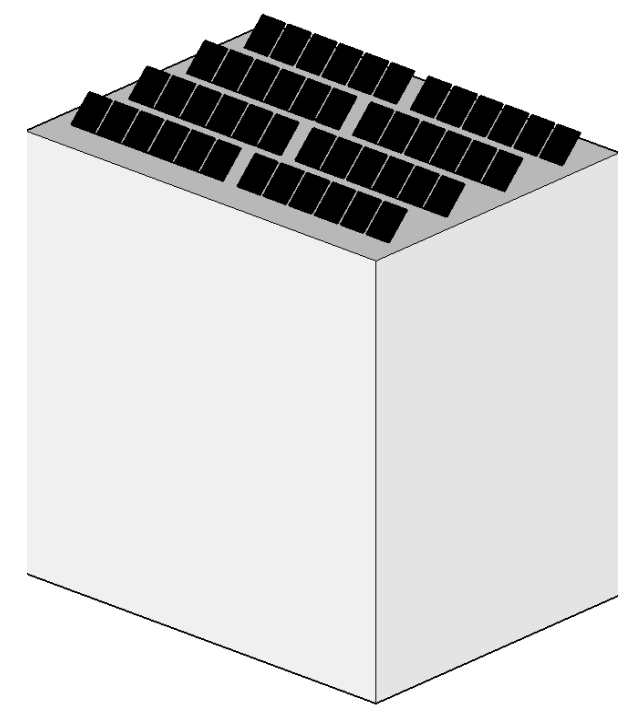

Fig. 6. Roof installation (R)

\subsection{Façade installation of the solar energy system}

Roof of the building can be very often occupied by technology systems and therefore there is very limited space for solar collector installation in reality. Due to this fact, façade integration of solar energy system is studied as an alternative as well. First sub-alternative of façade installation considers the area $140 \mathrm{~m}^{2}$ which is $22 \%$ of total area of the south wall (fully using the opaque part of the facade for 9 floors, see Fig. 7). While side by side installation considers $70 \mathrm{~m}^{2}$ of PV panels and $70 \mathrm{~m}^{2}$ of solar thermal collectors, PVT collectors occupy the whole area of $140 \mathrm{~m}^{2}$. In fig 7 . windows are represented by blue colour and solar installation by black colour. Because of potential green vegetation in the front of south façade in future, only upper 5 floors were simulated as well in second sub-alternative (see Fig. 7). Area of energy-active façade in this case is only $78 \mathrm{~m}^{2}$. Therefore only $39 \mathrm{~m}^{2}$ of PV panels and $39 \mathrm{~m}^{2}$ of solar thermal collectors were considered in side by side alternative, while considering $78 \mathrm{~m}^{2}$ of PVT collectors.
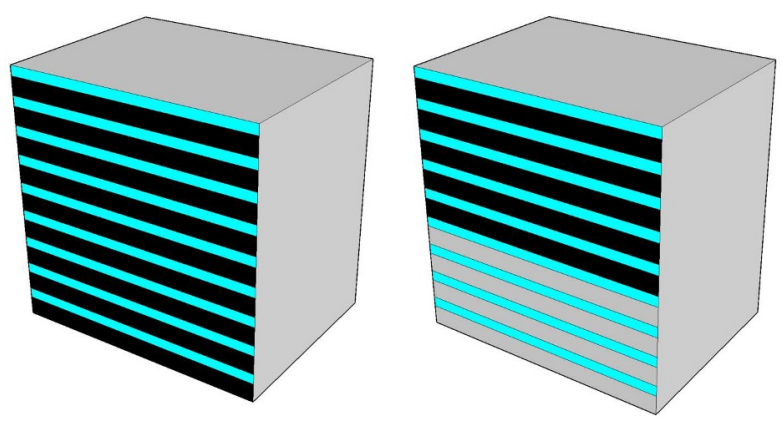

Fig. 7. Façade glazed PVT collectors installed in nine floors (F9) and in five floors (F5)

Results of simulation study for three different climatic location are shown in Fig. 9 and in Tab. 1. It is evident that facade installation of PVT collectors achieves about $25 \%$ lower energy gains compared to roof installation (both heat and electricity). When performance of PVT collectors is compared with side by side installation of PV modules and solar thermal collectors, PVT collectors achieve significantly higher energy gains, especially in case of the heat. The increase of thermal and electrical production thanks to PVT design is shown in Tab. 2.

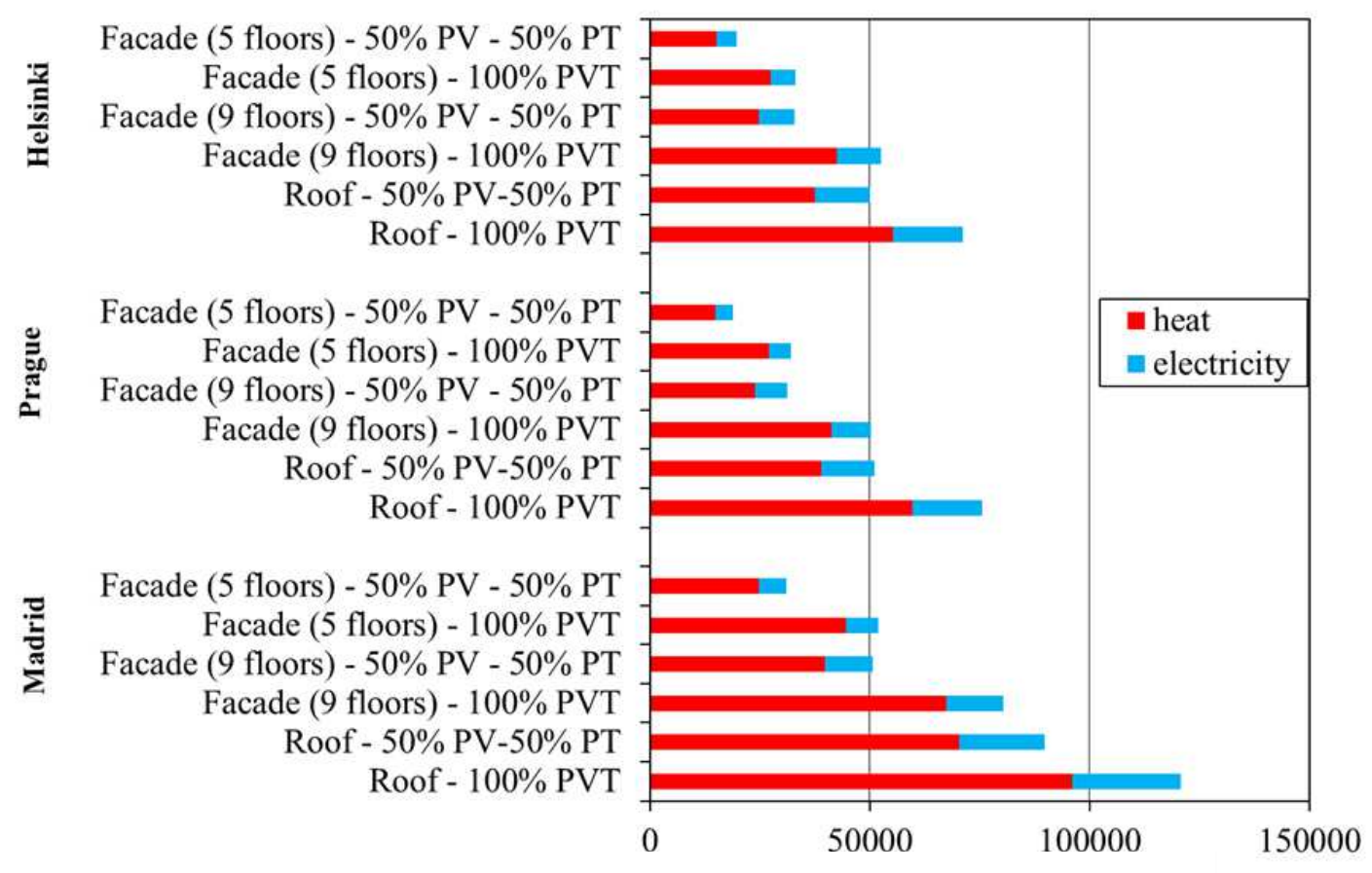

Fig. 8. Results of simulation study 
Table 2. Increase of energy production of PVT alternative compared to side-by-side installation

\begin{tabular}{|c|l|c|c|}
\hline Location & Variant & Heat & Electricity \\
\hline \multirow{3}{*}{ Madrid } & Roof & $37 \%$ & $27 \%$ \\
\cline { 2 - 4 } & Façade 9 floors & $70 \%$ & $19 \%$ \\
\cline { 2 - 4 } & Façade 5 floors & $79 \%$ & $22 \%$ \\
\hline \multirow{3}{*}{ Prague } & Roof & $53 \%$ & $32 \%$ \\
\cline { 2 - 4 } & Façade 9 floors & $72 \%$ & $21 \%$ \\
\cline { 2 - 4 } & Façade 5 floors & $81 \%$ & $23 \%$ \\
\hline \multirow{3}{*}{ Helsinki } & Roof & $47 \%$ & $28 \%$ \\
\cline { 2 - 4 } & Façade 9 floors & $72 \%$ & $23 \%$ \\
\cline { 2 - 4 } & Façade 5 floors & $81 \%$ & $25 \%$ \\
\hline
\end{tabular}

\section{Conclusion and outlook}

Simulation analysis was done with a detailed model of glazed solar PVT collector experimentally validated with testing of prototypes. Two alternatives (integrated and separated) of the new concept of glazed solar PVT collector with polysiloxane gel encapsulation of PV cells have been presented.

The results from simulation study of the given multifamily building have shown a large potential for achieving the higher solar fraction compared to separate installation of conventional technologies. Increase of electricity production due to PVT solution vary from $19 \%$ to $32 \%$. Increase of thermal production differs between façade and roof alternative. Increase of thermal production for roof alternative ranges from $37 \%$ to $53 \%$. The increase is much higher in the façade alternative and ranges from $71 \%$ to $81 \%$.

\section{References}

[1] Matuska, T. (2014). Performance and Economic Analysis of Hybrid PVT Collectors in Solar DHW System, Energy Procedia, Volume 48, 2014, pp. 150-156. https://doi: 10.1016/j.egypro.2014.02.019.

[2] Zondag, H.A, Van Helden, W.G.J. 2002. Stagnation temperature in PVT collectors. PV in Europe, Rome (Italy).

[3] Harrison, S., \& Cruickshank, C. A. (2012). A review of strategies for the control of high temperature stagnation in solar collectors and systems. Energy Procedia.,30,pp.793-804 https://doi.org/10.1016/j.egypro.2012.11.090

[4] Lammle, M., Thoma, C., \& Hermann, M. (2016). A PVT Collector Concept with Variable Film Insulation and Low-emissivity Coating. Energy Procedia (Vol. 91, pp. 72-77). https://doi.org/10.1016/j.egypro.2016.06.174

[5] Matuska, T., Sourek, B., Jirka, V., \& Pokorny, N. (2015). Glazed PVT Collector with Polysiloxane Encapsulation of PV Cells: Performance and Economic Analysis. International Journal of Photoenergy, 2015. https://doi.org/10.1155/2015/718316

[6] Poulek, V., Strebkov, D. S., Persic, I. S., \& Libra, M. (2012). Towards 50 years lifetime of PV panels laminated with silicone gel technology. Solar Energy, 86 (10), 3103-3108. https://doi.org/10.1016/j.solener.2012.07.013

[7] Bergene, T., Lovvik, O., 1995. Model calculations on a flat-plate solar heat collector with integrated solar cells. Solar Energy 55, 453-462.

[8] Zondag, H.A., De Vries, D.D., Van Helden, W.G.J., Van Zolingen, R.J.C., Van Steenhoven, A.A., 2002. The thermal and electrical yield of a PV-thermal collector. Solar Energy 72, 113-128

[9] Haurant, P., Ménézo, CH., Gailard, L. Dupeyrat, P., 2015. Dynamic numerical model of a high efficiency PV-T collector integrated into a domestic hot water system, Solar Energy 111, 68-81.

[10] Guarracino, I., Mellor, A., Ekins-Daukes, N., J., Markides CH., N., 2016. Dynamic coupled thermaland-electrical modelling of sheet-and-tube hybrid photovoltaic/thermal (PVT) collectors. Applied Thermal Engineering vol. 101, 778-795.

[11] Chow, T.T., 2003. Performance analysis of photovoltaic-thermal collector by explicit dynamic model. Solar Energy, vol. 75, 143-152.

[12] TRNSYS 17, "TRaNsient SYstem Simulation program", Solar Energy Laboratory, University of Winconsin-Madison, 2012.

[13] Florschuetz, W. L. 1979. Extension of the HottelWhilier model to the analysis of combined photovoltaic/thermal flat plate collector. Solar Energy, vol. 22, pp. 361-366.

[14] Pokorny, N., Matuska, T., Sourek B., 2015. Modelling of glazed liquid PV-T collector with use of detail model, in Proceedings of the Building Simulation International Conference (BS '15), Hyderabad, India.

\section{Acknowledgment}

This work has been supported by the Ministry of Education, Youth and Sports within National Sustainability Programme I, project No. LO1605. 